\title{
PACAP is Protective Against Cellular Stress in Retinal Pigment Epithelial Cells
}

\author{
Eszter Fábián ${ }^{1}\left({ }^{10} \cdot\right.$ Gabriella Horváth $^{1} \cdot$ Balázs Opper $^{1} \cdot$ Tamás Atlasz $^{1,2} \cdot$ Gábor Tóth $^{3}$ · Dóra Reglődi ${ }^{1}$
}

Accepted: 11 January 2021 / Published online: 9 February 2021

(c) The Author(s) 2021

\begin{abstract}
The integrity of the innermost, pigment epithelial layer of the retina is crucial for the photoreceptor survival and for maintaining the outer blood-retina barrier. In several ocular degenerations, such as diabetic retinopathy or macular edema, the stress caused by various harmful stimuli (hypoxia, oxidative stress, hyperosmosis) lead to severe molecular biological changes in this layer, promoting neovascularization of the retina. Pituitary adenylate cyclase activating polypeptide (PACAP) occurs throughout the whole body, including the eye. It has numerous functions in the retina, including the previously described anti-apoptotic and anti-angiogenic effects in retinal pigment epithelial cells. The aim of this present study was to investigate the influence of PACAP on different stress factors. In accordance with previous findings, PACAP significantly ameliorated the increased Hif1- $\alpha$ levels in hypoxic conditions. $\mathrm{In}_{2} \mathrm{O}_{2}$-induced oxidative stress PACAP had an anti-apoptotic effect, it could decrease the expression of cytochrome- $c$ and p53, while it upregulated the concentration of three antioxidants, namely SOD2, PON2 and thioredoxin. In conclusion, we provided new information on the molecular biological background of the retinoprotective effect of PACAP.
\end{abstract}

Keywords PACAP $\cdot$ ARPE $\cdot$ Oxidative stress $\cdot$ Hypoxia $\cdot$ Hyperosmotic stress

\section{Introduction}

The retinal pigment epithelial (RPE) cells form the outermost single layer of the retina between the Bruch's membrane and the photoreceptor cells. The cells are interconnected by tight junctions, thus they play a crucial role in forming the outer blood-retina barrier. With long microvilli on their apical surface interdigitating with the outer segments of rods and cones, RPE cells are also essential in maintaining the visual cycle (Bazan 2008). Moreover, these cells secrete different factors, such as vascular endothelial growth factor (VEGF), which, among others, regulates the neovascularization of the retina (Amoaku et al. 2020).

Eszter Fábián

eszter.fabian@aok.pte.hu

1 MTA-PTE PACAP Research Group, Department of Anatomy, Medical School, University of Pecs, Szigeti u. 12., Pecs, Hungary

2 Department of Sportbiology, University of Pecs, Pecs, Hungary

3 Department of Medical Chemistry, University of Szeged, Szeged, Hungary
Therefore, impairment of RPE cells stays in the background of many ocular degenerations, such as age-related macular degeneration (Kook et al. 2008), retinal detachment or diabetic retinopathy (DR). The latter is the most common cause of vision loss among working-age adults worldwide (Arfken et al. 1998; Leasher et al. 2016). The most important process in the pathogenesis of DR is the neovascularization occurring after hyperglycemic conditions. In addition to hyperglycemia, hypoxia, oxidative and hyperosmotic stresses also play a critical role in the development of DR and diabetic macular edema (DME; Abdullah 2018). Among the earliest signs of DR is the loss of pericytes and endothelial cells, which results in ischemia/hypoxia, leading to VEGF upregulation via activation of hypoxia inducible factors (Hif) (Ejaz et al. 2008; Huang et al. 2015). Elevated VEGF concentration leads not only to neovascularization, but also increases vasopermeability resulting in osmotic changes (Rodríguez et al. 2019). Retinal degeneration occurs already in the early stages of DR. Apoptosis of retinal cells causes mitochondrial dysfunction and increases the level of reactive oxygen species, resulting in oxidative stress (Joussen et al. 2007; Sasaki et al. 2010). These findings justify the search for 
novel therapeutics focusing not only to VEGF inhibition, but prevention of hypoxia, oxidative and hyperosmotic stress.

Pituitary adenylate cyclase activating polypeptid (PACAP) is a neuropeptide with various functions throughout the whole body and it seems to be an important neurotrophic agent with a general cytoprotective effect (Gaal et al. 2008; Toth et al. 2020; Maugeri et al. 2020a; Szegeczki et al. 2019; Girard et al. 2020; Martínez-Rojas et al. 2020). PACAP is widely distributed not only in the central nervous system, but in the periphery as well, exerting several beneficial actions. Following nerve injury PACAP is able to enhance the remyelinization of the nerve fibers by activating Schwann cells and promoting cytokine release (Armstrong et al. 2008; Maugeri et al. 2020b). PACAP was found to be protective in numerous cancerous diseases, such as breast, prostate and colon tumors and in both glio- and neuroblastomas as well (D'Amico et al. 2013; Maugeri et al. 2016, 2018; Moody et al. 2016). PACAP exerts diverse effects in various parts of the eye (Wang et al. 1995; Atlasz et al. 2016). In the cornea PACAP could induce epidermal growth factor receptor activation and it was proved to be protective against ultraviolet-B radiation (Maugeri et al. 2019a, b, c, 2020a). The retinoprotective function was mostly studied on the inner layers of the retina (Kovacs et al. 2020; Atlasz et al. 2016), only a few research groups focused on the outermost, pigment epithelial layer. The first results concerning the effects of PACAP came from Zhang and coworkers. Presence of mRNA for PAC1 and VPAC1 receptors was confirmed in unstimulated ARPE-19 cells (Zhang et al. 2013). We already showed the anti-apoptotic and anti-angiogenic effects of PACAP in human adult retinal pigment epithelial cell line-19 (ARPE-19) under the above mentioned circumstances (Mester et al. 2011; Fabian et al. 2012, 2019; Maugeri et al. 2019a, b, c). $\mathrm{In}_{2} \mathrm{O}_{2}$-induced oxidative stress, PACAP was found to be anti-apoptotic in a dose dependent manner (Mester et al. 2011). Subsequently, we proved that PACAP protected the cells via regulating the Akt and MAPK pathways (Szabo et al. 2012). The antiapoptotic effect was further investigated, and we found that PACAP ameliorated the overexpression of Bad, Bax, Hif1- $\alpha$ and heat shock proteins (Fabian et al. 2012). According to Maugeri et al. (2017) PACAP could also decrease the Hif1- $\alpha$ and Hif $1-\alpha$-induced VEGF expression in hyperglycemic/ hypoxic conditions, which was also proved in vivo in a rat model (D’Amico et al. 2015). In the present paper, we further examined the molecular mechanisms, through which PACAP exerts its cytoprotective functions under hypoxia, oxidative and hyperosmotic stress. Therefore, we studied the effect of PACAP on diverse stress factors in vitro and on the RPE cell numbers in vivo.

\section{Materials and Methods}

\section{Animals and Histological Analysis of the Retina}

We performed bilateral common carotid artery occlusion (BCCAO) on male Wistar rats $(\mathrm{n}=32)$ weighing $250-300 \mathrm{~g}$. Under isoflurane anesthesia, the arteries were exposed and ligated with a 3-0 filament. Immediately after the operation, PACAP ( $100 \mathrm{pmol} / 5 \mu \mathrm{l}$ saline) was injected intravitreally into the right eye with a Hamilton syringe. The left eye received the same volume of vehicle. A group of animals underwent anesthesia and all steps of the surgical procedure, except ligation of the carotid arteries. These animals served as sham-operated saline- or PACAP-treated animals. Experimental procedures were performed following institutional ethical guidelines (BA02/2000-24/2011, University of Pécs). Eyes were removed after sacrificing the animals with an overdose of anesthetics 2 weeks later. Histological analysis was performed as described previously (Atlasz et al. 2007). Briefly, retinas were dissected in phosphate buffered saline (PBS), fixed in $4 \%$ paraformaldehyde dissolved in $0.1 \mathrm{M}$ phosphate buffer, embedded in Durcupan ACM resin. Then $2 \mu \mathrm{m}$ thick sections were cut and stained with toluidine blue (Sigma, Budapest, Hungary). Four tissue blocks obtained from at least four rats were prepared and central retinal areas within $1 \mathrm{~mm}$ from the optic nerve were used $(\mathrm{n}=5$ measurements from one tissue block). Number of cells/100 $\mu \mathrm{m}$ section length in the pigment epithelial layer was counted on digital photographs taken with a Nikon Eclipse camera, using the Spot program and were presented as mean \pm SEM. Statistical analysis was performed using ANOVA followed by Bonferroni's post hoc analysis.

\section{Cell Culture}

ARPE-19 cells, obtained from the American Type Culture Collection (ATCC, Manassas, VA), were grown in Dulbecco's modified Eagle medium/F12 (DMEM/F12) with 10\% fetal bovine serum, $100 \mathrm{U} / \mathrm{ml}$ penicillin, and $100 \mu \mathrm{g} / \mathrm{ml}$ streptomycin in a humidified incubator at $37{ }^{\circ} \mathrm{C}$ in $5 \% \mathrm{CO}_{2}$. Culture medium was changed every second day. We treated the cells in serum-free DMEM/F12 medium for $24 \mathrm{~h}$. All cell culture reagents were from Sigma-Aldrich (St. Louis, MO). PACAP1-38 was synthesized as previously described (Jozsa et al. 2005).

\section{Human Cell Stress Array}

The cell stress array was performed from cell homogenates using Human Cell Stress Array Kit (R\&D Systems; Biomedica Hungaria, Budapest, Hungary). The array is based 
on the binding of sample proteins and carefully selected captured antibodies spotted on nitrocellulose membranes. The ARPE-19 cells were treated with $200 \mathrm{mM}$ sucrose, $250 \mu \mathrm{M}$ $\mathrm{H}_{2} \mathrm{O}_{2}$ and $200 \mu \mathrm{M} \mathrm{CoCl}_{2}$ with or without co-treatment with PACAP. Concentrations of these substances were based on earlier studies (Mester et al. 2011). The array kit contains all buffers, detection antibodies, and membranes necessary for the measurements. It was performed as described by the manufacturer, similarly to our previous studies (Fabian et al. 2019). Briefly, after blocking the array membranes for $1 \mathrm{~h}$, we added reconstituted detection antibody cocktail for another $1 \mathrm{~h}$ at room temperature. The membranes were then incubated with $1 \mathrm{ml}$ of cellular extracts at $2-8{ }^{\circ} \mathrm{C}$ overnight on a rocking platform. After washing with buffer three times, we added horseradish-peroxidase conjugated streptavidin to each membrane. They were exposed to a chemiluminescent detection reagent, then developed on an X-ray film and scanned. Images were analyzed using the ImageJ software. For statistical analysis, we performed two-way ANOVA with Bonferroni's post hoc test with GraphPad Prism 6.01. program, $\mathrm{p}<0.05$ was considered significant.

\section{Results}

\section{Histological Analysis}

We counted the pigment epithelial cells in $100 \mu \mathrm{m}$ of the retina of rats after BCCAO. We found $5.8 \pm 0.374$ cell bodies in $100 \mu \mathrm{m}$ in average in control retinas. PACAP alone was injected into the right eye of the control animals, but it did not cause any changes in the number of pigment epithelial cells $(5.4 \pm 0.4$ cell bodies in $100 \mu \mathrm{m})$. Though in the left eye of BCCAO operated animals (saline treated) the thickness of the whole retina, the thickness of each individual layer, and the number of ganglion cells in $100 \mu \mathrm{m}$ strongly decreased (Werling et al. 2014), the pigment epithelial cells did not suffer any changes in number $(5.4 \pm 0.245$ cell bodies in average). The right eyes (PACAP treated) had 5.6 \pm 0.51 pigment cells in $100 \mu \mathrm{m}$ (Fig. 1).

\section{Cell Stress Array}

By using cell stress array, we detected the changes in the expression of 26 different molecular biological markers (Fig. 2). Hif1- $\alpha$ levels were strongly elevated following sucrose, $\mathrm{H}_{2} \mathrm{O}_{2}$, and $\mathrm{CoCl}_{2}$ administration. In case of hypoxia a significant decrease could be observed with PACAP coadministration, while only a slight decrease occurred in hyperosmotic conditions (Fig. 3c). The $\mathrm{H}_{2} \mathrm{O}_{2}$-induced oxidative stress activated cytochrome- $c$ and phosphorylated p53 levels. PACAP significantly lowered the expression of both, thus proved to be anti-apoptotic in this model. Following
$\mathrm{H}_{2} \mathrm{O}_{2}$ administration, the levels of three important antioxidants, namely PON2, SOD2 and thioredoxin increased, PACAP further elevated the expression of the latter one (Fig. 3a). In hypoxia, the concentration of carbonic-anhydrase IX (CAIX) and SOD2 was significantly lower compared to controls, while in hyperosmosis the level of HSP-60 was decreased in addition to CAIX and SOD2. While CAIX concentration was attenuated by PACAP in both hypoxic and hyperosmotic conditions, the expression of SOD2 was decreased after PACAP treatment in hypoxia, but increased in hyperosmosis (Fig. 3b). In $\mathrm{CoCl}_{2}$-induced stress HSP-60 was also significantly upregulated by PACAP.

\section{Discussion}

Several papers suggest that DR is not only a vascular damage, but neurodegeneration also plays a pivotal role in its pathogenesis (Zhang et al. 2013; Simo and Hernandez 2015; Rossino et al. 2019). Various neuropeptides and their receptors, including VIP and PACAP, were detected in the retina (Nakamachi et al. 2012) and proved to be neuroprotective against different harmful stimuli, thus they can be considered as potential therapeutic agents in DR (Atlasz et al. 2010a, b; Nakamachi et al. 2012; Lakk et al. 2015; Shioda et al. 2016; Ye et al. 2019). In vivo studies confirmed that intravitreal or topical administration of PACAP not only improves ERG responses, but attenuates inflammatory processes, protects neurons in the ganglion cell layer and diminishes the thinning of the rat retina (Danyadi et al. 2014; Vaczy et al. 2016; Werling et al. 2017; Atlasz et al. 2018). In streptozotocininduced diabetes after intravitreal PACAP administration attenuated levels of IL- $1 \beta$ and VEGF were found (D'Amico et al. 2017). PACAP was also able to prevent the damage of the outer blood-retina barrier in diabetic rats (D'Amico et al. 2019; Scuderi et al. 2013). In previous studies, we demonstrated the anti-apoptotic and anti-angiogenic effects of PACAP (Mester et al. 2011; Szabo et al. 2012; Fabian et al. 2012). We have recently suggested that PACAP administration might be a possible therapy against complications of DR by maintaining the cellular junctions between the retinal pigment epithelial cells and by inhibiting their VEGF secretion (Fabian et al. 2019). In this present study, we confirmed further molecular mechanisms, through which PACAP could exert these functions. Hif1 is a major transcriptional regulator, composed of $\alpha$ and $\beta$ subunits (Semenza 2003; Ziello et al. 2007). Both are expressed at a constant rate in all cells, except for the cells of the peripheral blood, whereas the $\alpha$ subunit is promptly degraded by an oxygen-dependent mechanism. In hypoxic conditions, Hif $1-\alpha$ is stabilized, dimerizes with Hif1- $\beta$, and translocates to the nucleus, where, depending on the cell type, it induces the transcription of over 60 different genes, including VEGF (Forsythe et al. 1996; 

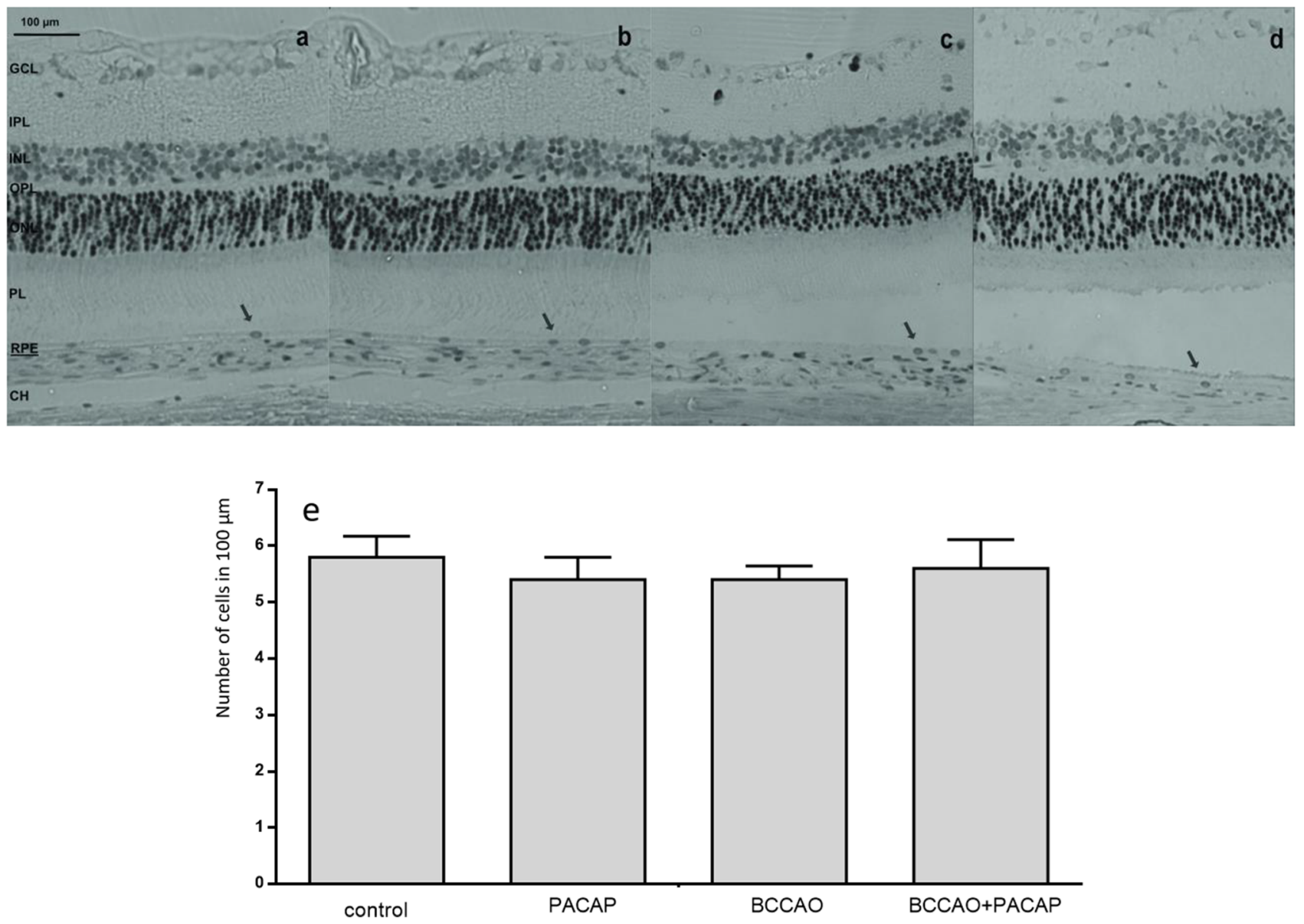

Fig. 1 Retina sections stained with toluidine blue of control (a), PACAP (b), BCCAO (c), and BCCAO+PACAP (d) animals. Scale $=100 \mu \mathrm{m}$. Number of cells $/ 100 \mu \mathrm{m}$ section length in the retinal pigment epithelial layer (RPE) was measured. No significant difference was observed. Arrows show pigment epithelial cells. e Average

Kurihara et al. 2014). Thus, downregulation of Hif1- $\alpha$ could be in the molecular background of the anti-VEGF function of PACAP. In a recent study, the protective function of PACAP was shown in a combined hyperglycemic/hypoxic environment in ARPE-19 cells (Maugeri et al. 2017). The RPE cells were kept in normal glucose medium $(5.5 \mathrm{mM})$ for a week, then, half of the cells were switched in high glucose medium $(25 \mathrm{mM})$ for another 7 days. On the second week, the cells were exposed to $100 \mu \mathrm{M}$ deferoxamine mesylate salt alone, or in combination with $100 \mathrm{nM}$ PACAP. The researchers found that PACAP reduced the elevated levels of Hif $1-\alpha$, while it increased the expression of Hif3- $\alpha$. In accordance with this, in the present study we also found the same effect of PACAP in two different harmful conditions (hypoxia and hyperosmotic stress), whereas we could not prove this ameliorating function of PACAP in oxidative stress.

CAIX is a transmembrane protein catalyzing the hydration of $\mathrm{CO}_{2}$. As it is another downstream target of Hif1- $\alpha$, number of RPE cells $/ 100 \mu \mathrm{m}$ section length. $C H$ choroidea, $R P E$ pigment epithelium, $O N L$ outer nuclear layer, $O P L$ outer plexiform layer, $I N L$ inner nuclear layer, $I P L$ inner plexiform layer, $G C L$ ganglion cell layer

it has also been showed to be a cellular marker of hypoxia. In physiological conditions, especially in dark adaptation, the retina is proposed to be hypoxic (Lahdenranta et al. 2001; Arden et al. 2005; de Gooyer et al. 2006; Hughes et al. 2010). This fact would suggest high control levels of both Hif1- $\alpha$ and its downstream molecules. In ARPE19 cells, we did not find elevated Hif $1-\alpha$ expression, but under control conditions, the concentration of CAIX was extremely high. PACAP alone, and in co-administration could diminish the effect of the harmful agents $\left(\mathrm{CoCl}_{2}\right.$ and sucrose). Oxidative stress, a primary causative event in DR (Hernandez et al. 2016) is associated with increased levels of reactive oxygen species (ROS). In our present study, after $\mathrm{H}_{2} \mathrm{O}_{2}$ administration elevated expression of three antioxidants was detected, such as PON2, thioredoxin and 


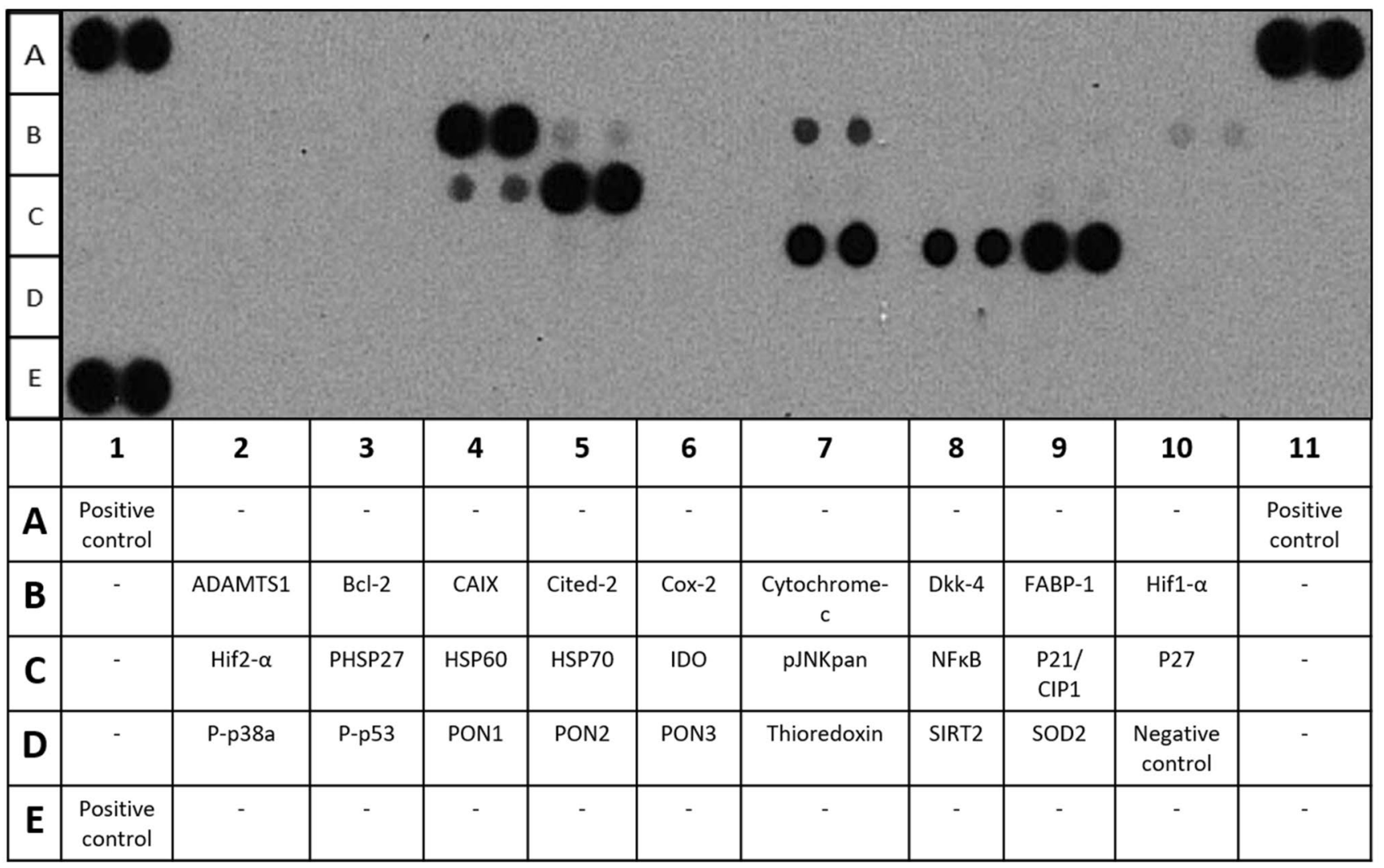

Fig. 2 Representative picture and the table of detectable markers of the cells stress array

SOD2. PACAP was able to further induce the thioredoxin synthesis, creating an antioxidant rich environment, which is essential against ROS.

In accordance with our previous findings PACAP could attenuate the elevated concentrations of cytochrome- $c$ and p53 (Atlasz et al. 2010b; Szabadfi et al. 2010; Fabian et al. 2012). In contrast, analysis of the histological structure of the retina did not reveal any numerical changes in the pigment epithelial layer, while the thickness of the entire retina, especially the outer plexiform layer, was significantly reduced (Werling et al. 2014). It is characteristic for several retinal injuries that the inner retinal layers suffer a more severe morphological lesion, while the pigment epithelial layer is seemingly not damaged (Werling et al. 2014). However, the several biochemical changes indicate the severe functional damage in these cells, probably leading to further damage in the inner layers. In summary, we found that, in accordance with previous studies, PACAP could counteract some of the negative changes in the pigment epithelial layer further confirming the retinoprotective effects of the retina. 
Fig. 3 a Graph of the cell stress array in oxidative stress. ARPE-19 cells were treated with PACAP, $\mathrm{H}_{2} \mathrm{O}_{2}$ and $\mathrm{H}_{2} \mathrm{O}_{2}+\mathrm{PACAP}$, vs. control $* \mathrm{P}<0.5, * * \mathrm{P}<0.001$, vs. $\mathrm{H}_{2} \mathrm{O}_{2}$ treated ${ }^{\#} \mathrm{P}<0.5,{ }^{\# \#} \mathrm{P}<0.001$. b Graph of the cells stress array in hyperosmotic stress. ARPE-19 cells were treated with PACAP, sucrose and sucrose + PACAP, vs. control $* \mathrm{P}<0.5 ; * * \mathrm{P}<0.001$, vs. sucrose treated ${ }^{\#} \mathrm{P}<0.5$, ${ }^{\# \#} \mathrm{P}<0.001$. c Graph of the cells stress array in hypoxic stress. ARPE-19 cells were treated with PACAP, $\mathrm{CoCl}_{2}$ and $\mathrm{CoCl}_{2}+$ PACAP, vs. control $* \mathrm{P}<0.5, * * \mathrm{P}<0.001$, vs. $\mathrm{CoCl}_{2}$ treated ${ }^{\#} \mathrm{P}<0.5,{ }^{\# \#} \mathrm{P}<0.001$
A Control
PACAP
$\mathrm{H}_{2} \mathrm{O}_{2}$
$\mathrm{H}_{2} \mathrm{O}_{2}+$ PACAP

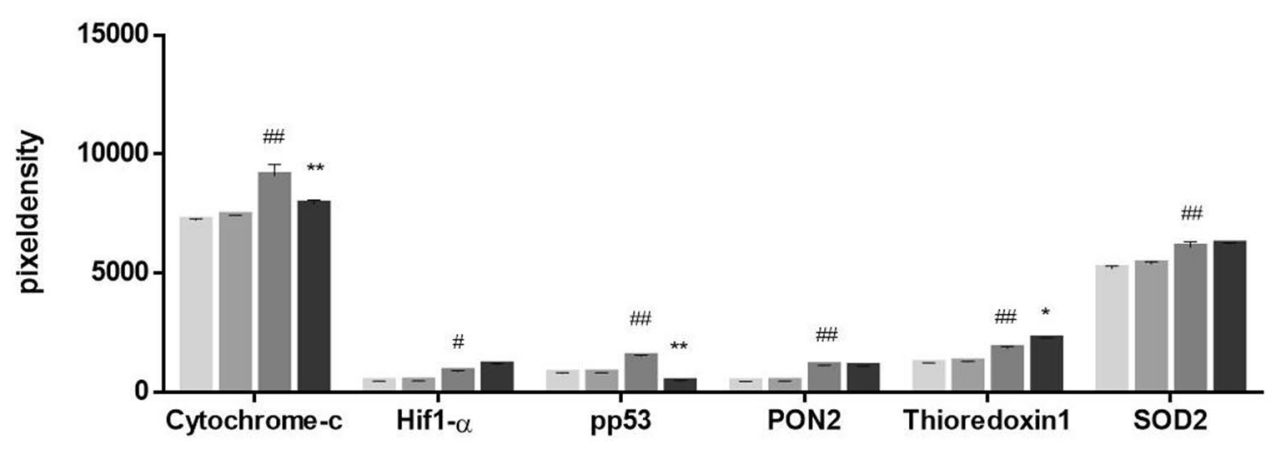

B

Control

PACAP

Sucrose

Sucrose+PACAP

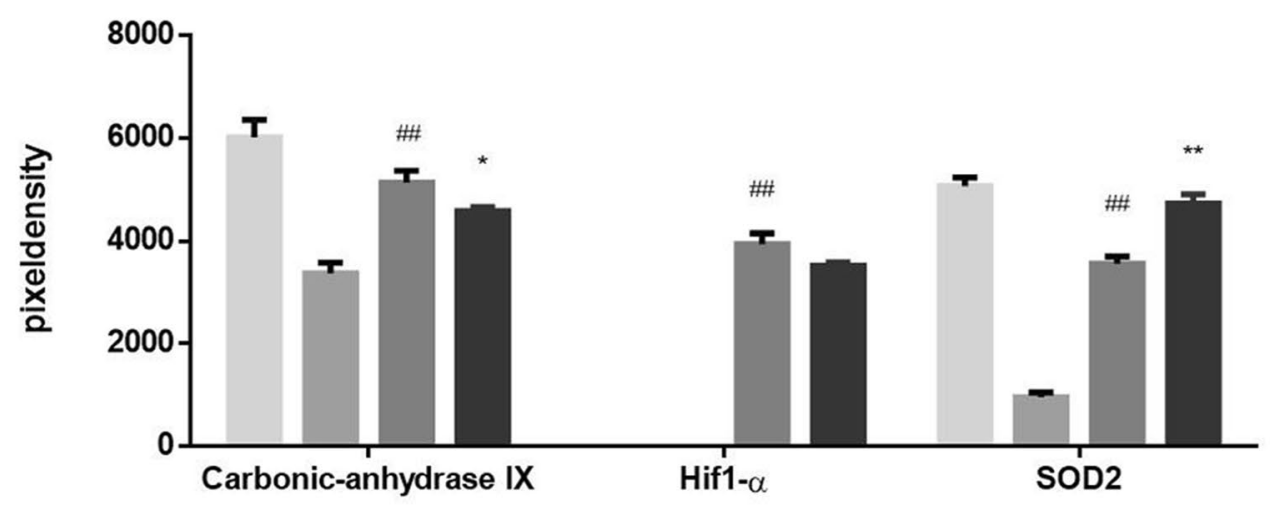

C

Control

PACAP

$\mathrm{CoCl}_{2}$

$\mathrm{CoCl}_{2}+\mathrm{PACAP}$

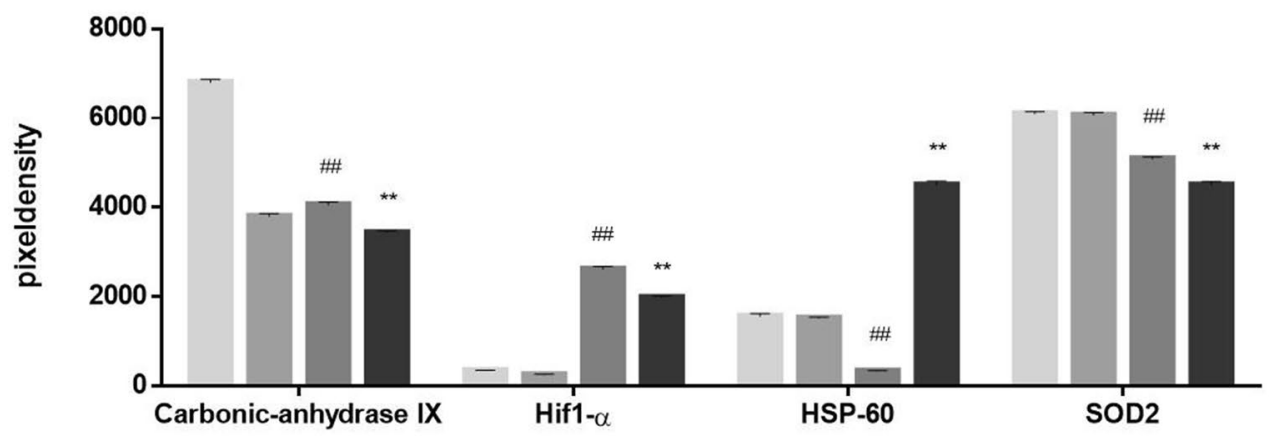

Acknowledgements This study was supported by NAP20171.2.1-NKP-2017-00002; GINOP-2.3.2-15-2016-00050 "PEPSYS", KA-2016-03, KA-2017-17 MTA-TKI14016; NKFIH K119759, NKFIH K135457, NKFIH FK129190, FIKPIII, Bolyai Scholarship, PTE AOKTANDEM 2019 Grant, EFOP-3.6.3-VEKOP-16-2017-00009, EFOP3.6.1.-16-2016-00004 Comprehensive Development for Implementing Smart Specialization Strategies at the University of Pécs; New Excellence Program, EFOP-3.6.2-00008, "The role of neuro-inflammation in neurodegeneration: from molecules to clinics", Higher Education Institutional Excellence Program of the Ministry of Human Capacities in Hungary, within the Framework of the 20765-3/2018/FEKUTSTRAT.
Funding Open Access funding provided by University of Pécs.

Data Availability The datasets generated during and/or analysed during the current study are available from the corresponding author on reasonable request.

\section{Compliance with Ethical Standards}

Conflict of interest The authors declare that they have no conflicts of interest. 
Open Access This article is licensed under a Creative Commons Attribution 4.0 International License, which permits use, sharing, adaptation, distribution and reproduction in any medium or format, as long as you give appropriate credit to the original author(s) and the source, provide a link to the Creative Commons licence, and indicate if changes were made. The images or other third party material in this article are included in the article's Creative Commons licence, unless indicated otherwise in a credit line to the material. If material is not included in the article's Creative Commons licence and your intended use is not permitted by statutory regulation or exceeds the permitted use, you will need to obtain permission directly from the copyright holder. To view a copy of this licence, visit http://creativecommons.org/licenses/by/4.0/.

\section{References}

Abdullah SAK (2018) Role of oxidative stress, inflammation, hypoxia and angiogenesis in the development of diabetic retinopathy. Saudi J Ophthalmol 32(4):318-323

Amoaku WM, Ghanchi F, Bailey C, Banerjee S, Banerjee S, Downey L, Gale R, Hamilton R, Khunti K, Posner E, Quhill F, Robinson S, Setty R, Sim D, Varma D, Mehta H (2020) Diabetic retinopathy and diabetic macular oedema pathways and management: UK Consensus Working Group. Eye (Lond) 34(Suppl 1):1-51

Arden GB, Sidman RL, Arap W, Schlingemann RO (2005) Spare the rod and spoil the eye. Br J Ophthalmol 89(6):764-769

Arfken CL, Reno PL, Santiago JV, Klein R (1998) Development of proliferative diabetic retinopathy in African-Americans and whites with type 1 diabetes. Diabetes Care 21(5):792-795

Armstrong BD, Abad C, Chhith S, Cheung-Lau G, Hajji OE, Nobuta H, Waschek JA (2008) Impaired nerve regeneration and enhanced neuroinflammatory response in mice lacking pituitary adenylyl cyclase activating peptide. Neuroscience 151(1):63-73

Atlasz T, Babai N, Kiss P, Reglodi D, Tamas A, Szabadfi K, Toth G, Hegyi O, Lubics A, Gabriel R (2007) Pituitary adenylate cyclase activating polypeptide is protective in bilateral carotid occlusion-induced retinal lesion in rats. Gen Comp Endocrinol 153:108-114

Atlasz T, Szabadfi K, Kiss P, Racz B, Gallyas F, Tamas A, Gaal V, Marton Z, Gabriel R, Reglodi D (2010a) Review of pituitary adenylate cyclase activating polypeptide in the retina: focus on the retinoprotective effects. Ann N Y Acad Sci 1200:128-39

Atlasz T, Szabadfi K, Kiss P, Tamas A, Toth G, Reglodi D, Gabriel R (2010b) Evaluation of the protective effects of PACAP with cellspecific markers in ischemia-induced retinal degeneration. Brain Res Bull 81:497-504

Atlasz T, Vaczy A, Werling D et al (2016) Chap 30: protective effects of PACAP in the retina. In: Reglodi D, Tamas A (eds) Pituitary adenylate cyclase activating polypeptide-PACAP. Springer, Berlin, pp 433-448

Atlasz T, Werling D, Song S, Szabo E, Vaczy A, Kovari P et al (2018) Retinoprotective effects ofTAT-bound vasoactive intestinal peptide and pituitary adenylate cyclase activating polypeptide. J MolNeurosci 68:397-407

Bazan NG (2008) Neurotrophins induce neuroprotective signaling in the retinal pigment epithelial cell by activating the synthesis of the anti-inflammatory and anti-apoptotic neuroprotectin D1. Adv Exp Med Biol 613:39-44

D'Amico AG, Scuderi S, Saccone S, Castorina A, Drago F, D'Agata V (2013) Antiproliferative effects of PACAP and VIP in serumstarved glioma cells. J Mol Neurosci 51(2):503-513

D'Amico AG, Maugeri G, Reitano R, Bucolo C, Saccone S, Drago F, D'Agata V (2015) PACAP modulates expression of hypoxia-inducible factors in streptozotocin-induced diabetic rat retina. J Mol Neurosci 57(4):501-509

D'Amico AG, Maugeri G, Rasà DM, Bucolo C, Saccone S, Federico C, Cavallaro S, Agata V (2017) Modulation of IL-1 $\beta$ and VEGF expression in rat diabetic retinopathy after PACAP administration. Peptides 97:64-69

D’Amico AG, Maugeri G, Rasà D, Federico C, Saccone S, Lazzara F, Fidilio A, Drago F, Bucolo C, Agata V (2019) NAP modulates hyperglycemic-inflammatory event of diabetic retina by counteracting outer blood retinal barrier damage. J Cell Physiol 234(4):5230-5240

Danyadi B, Szabadfi K, Reglodi D, Mihalik A, Danyadi T, Kovacs Z et al (2014) PACAP application improves functional outcome of chronic retinal ischemic injury in rats-evidence from electroretinographic measurements. J Mol Neurosci 54:293-299

de Gooyer TE, Stevenson KA, Humphries P, Simpson DA, Curtis TM, Gardiner TA, Stitt AW (2006) Rod photoreceptor loss in $\mathrm{Rho}^{-/-}$mice reduces retinal hypoxia and hypoxia-regulated gene expression. Investig Ophthalmol Vis Sci 47(12):5553-5560

Ejaz S, Chekarova I, Ejaz A, Sohail A, Lim CW (2008) Importance of pericytes and mechanisms of pericyte loss during diabetes retinopathy. Diabetes Obes Metab 10(1):53-63

Fabian E, Reglodi D, Mester L, Szabo A, Szabadfi K, Tamas A, Toth G, Kovacs K (2012) Effects of PACAP on intracellular signaling pathways in human retinal pigment epithelial cells exposed to oxidative stress. J Mol Neurosci 48(3):493-500

Fabian E, Reglodi D, Horvath G, Opper B, Toth G, Fazakas C, Vegh AG, Wilhelm I, Krizbai IA (2019) Pituitary adenylate cyclase activating polypeptide acts against neovascularization in retinal pigment epithelial cells. Ann N Y Acad Sci 1455(1):160-172

Forsythe JA, Jiang BH, Iyer NV, Agani F, Leung SW, Koos RD, Semenza GL (1996) Activation of vascular endothelial growth factor gene transcription by hypoxia-inducible factor 1 . Mol Cell Biol 16:4604-4613

Gaal V, Mark L, Kiss P, Kustos I, Tamas A, Kocsis B, Lubics A, Nemeth V, Nemeth A, Lujber L, Pytel J, Toth G, Reglodi D (2008) Investigation of the effects of PACAP on the composition of tear and endolymph proteins. J Mol Neurosci 36:321-329

Girard BM, Campbell SE, Beca KI, Perkins M, Hsiang H, May V, Vizzard MA (2020) Intrabladder PAC1 receptor antagonist, PACAP(6-38), reduces urinary bladder frequency and pelvic sensitivity in mice exposed to repeated variate stress (RVS). J Mol Neurosci. https://doi.org/10.1007/s12031-020-01649-x

Hernandez C, Dal Monte M, Simó R, Casini G (2016) Neuroprotection as a therapeutic target for diabetic retinopathy. J Diabetes Res 2016:9508-9541

Huang H, He J, Johnson D, Wei Y, Liu Y, Wang S, Lutty GA, Duh EJ, Semba RD (2015) Deletion of placental growth factor prevents diabetic retinopathy and is associated with Akt activation and HIF $1 \alpha$-VEGF pathway inhibition. Diabetes 64(1):200-212

Hughes JM, Groot AJ, van der Groep P, Sersansie R, Vooijs M, Diest PJ, Van Noorden CJF, Schlingemann RO, Klaassen I (2010) Active HIF-1 in the normal human retina. J Histochem Cytochem 58(3):247-254

Joussen AM, Smyth N, Niessen C (2007) Pathophysiology of diabetic macular edema. Dev Ophthalmol 39:1-12

Jozsa R, Hollosy T, Tamas A et al (2005) Pituitary adenylate cyclase activating polypeptide plays a role in olfactory memory formation in chicken. Peptides 26:2344-2350

Kook D, Wolf AH, Yu AL, Neubauer AS, Priglinger SG, Kampik A, Welge-Lüssen UC (2008) The protective effect of quercetin against oxidative stress in the human RPE in vitro. Investig Ophthalmol Vis Sci 49(4):1712-1720

Kovacs AK, Atlasz T, Werling D, Szabo E, Reglodi D, Toth GK (2020) Stability test of PACAP in eye drops. J Mol Neurosci. https://doi. org/10.1007/s12031-020-01532-9 
Kurihara T, Westenskow PD, Friedlander M (2014) Hypoxia-inducible factor (HIF)/vascular endothelial growth factor (VEGF) signaling in the retina. Adv Exp Med Biol 801:275-281

Lahdenranta J, Pasqualini R, Schlingemann RO, Hagedorn M, Stallcup WB, Bucana CD, Sidman RL, Arap W (2001) An anti-angiogenic state in mice and humans with retinal photoreceptor cell degeneration. Proc Natl Acad Sci USA 98(18):10368-10373

Lakk M, Denes V, Gabriel R (2015) Pituitary adenylate cyclase-activating polypeptide receptors signal via phospholipase c pathway to block apoptosis in newborn rat retina. Neurochem Res 40:1402-1409

Leasher JL, Bourne RR, Flaxman SR, Jonas JB, Keeffe J, Naidoo K et al (2016) Global estimates on the number of people blind or visually impaired by diabetic retinopathy: a meta-analysis from 1990 to 2010. Diabetes Care 39:1643-1649

Martínez-Rojas VA, Jiménez-Garduño AM, Michelatti D, Tosatto L, Marchioretto M, Arosio D, Basso M, Pennuto M, Musio C (2020) $\mathrm{ClC}$-2-like chloride current alterations in a cell model of spinal and bulbar muscular atrophy, a polyglutamine disease. J Mol Neurosci. https://doi.org/10.1007/s12031-020-01687-5

Maugeri G, D’Amico AG, Reitano R, Magro G, Cavallaro S, Salomone S, D'Agata V (2016) PACAP and VIP inhibit the invasiveness of glioblastoma cells exposed to hypoxia through the regulation of HIFs and EGFR expression. Front Pharmacol 7:139

Maugeri G, D’Amico AG, Saccone S, Federico C, Cavallaro S, D'Agata V (2017) PACAP and VIP inhibit HIF-1alpha-mediated VEGF expression in a model of diabetic macular edema. J Cell Physiol 232(5):1209-1215

Maugeri G, D'Amico AG, Rasà DM, Saccone S, Federico C, Cavallaro S, D’Agata V (2018) PACAP and VIP regulate hypoxia-inducible factors in neuroblastoma cells exposed to hypoxia. Neuropeptides 69:84-91

Maugeri G, D'Amico AG, Bucolo C, D'Agata V (2019a) Protective effect of PACAP-38 on retinal pigmented epithelium in an in vitro and in vivo model of diabetic retinopathy through EGFR-dependent mechanism. Peptides 119:170108

Maugeri G, D’Amico AG, Castrogiovanni P, Saccone S, Federico C, Reibaldi M, Russo A, Bonfiglio V, Avitabile T, Longo A, D'Agata V (2019b) PACAP through EGFR transactivation preserves human corneal endothelial integrity. J Cell Biochem 120(6):10097-10105

Maugeri G, D'Amico AG, Rasà DM, Federico C, Saccone S, Morello G, La Cognata V, Cavallaro S, D’Agata V (2019c) Molecular mechanisms involved in the protective effect of pituitary adenylate cyclase-activating polypeptide in an in vitro model of amyotrophic lateral sclerosis. J Cell Physiol 234(4):5203-5214

Maugeri G, D’Amico AG, Amenta A, Saccone S, Federico C, Reibaldi M, Russo A, Bonfiglio V, Avitabile T, Longo A, D'Agata V (2020a) Protective effect of PACAP against ultraviolet $B$ radiation-induced human corneal endothelial cell injury. Neuropeptides 79:101978

Maugeri G, D’Amico AG, Musumeci G, Reglodi D, D’Agata V (2020b) Effects of PACAP on Schwann cells: focus on nerve injury. Int $\mathbf{J}$ Mol Sci 21(21):8233

Mester L, Kovacs K, Racz B et al (2011) Pituitary adenylate cyclaseactivating polypeptide is protective against oxidative stress in human retinal pigment epithelial cells. J Mol Neurosci 43:35-43

Moody TW, Nuche-Berenguer B, Jensen RT (2016) VIP/PACAP, and their receptors and cancer. Curr Opin Endocrinol Diabetes Obes 23:38-47

Nakamachi T, Matkovits A, Seki T, Shioda S (2012) Distribution and protective function of pituitary adenylate cyclase-activating polypeptide in the retina. Front Endocrinol 3:145

Rodríguez ML, Pérez S, Mena-Mollá S, Desco MC, Ortega ÁL (2019) Oxidative stress and microvascular alterations in diabetic retinopathy: future therapies. Oxid Med Cell Longev 2019:4940825
Rossino MG, Dal Monte M, Casini G (2019) Relationships between neurodegeneration and vascular damage in diabetic retinopathy. Front Neurosci 13:1172

Sasaki M, Ozawa Y, Kurihara T, Kubota S, Yuki K, Noda K, Kobayashi S, Ishida S, Tsubota K (2010) Neurodegenerative influence of oxidative stress in the retina of a murine model of diabetes. Diabetologia 53(5):971-979

Scuderi S, D’Amico AG, Castorina A, Imbesi R, Carnazza ML, D'Agata V (2013) Ameliorative effect of PACAP and VIP against increased permeability in a model of outer blood retinal barrier dysfunction. Peptides 39:119-124

Semenza GL (2003) Targeting HIF-1 for cancer therapy. Nat Rev Cancer 3:721-732

Shioda S, Takenoya F, Wada N, Hirabayashi T, Seki T, Nakamachi T (2016) Pleiotropic and retinoprotective functions of PACAP. Anat Sci Int 91:313-324

Simo R, Hernandez C (2015) Novel approaches for treating diabetic retinopathy based on recent pathogenic evidence. Prog Retin Eye Res 48:160-180

Szabadfi K, Mester L, Reglodi D et al (2010) Novel neuroprotective strategies in ischemic retinal lesions. Int J Mol Sci 11:544-561

Szabo A, Danyadi B, Bognar E, Szabadfi K, Fabian E, Kiss P, Mester L, Manavalan S, Atlasz T, Gabriel R, Toth G, Tamas A, Reglodi D, Kovacs K (2012) Effect of PACAP on MAP kinases, Akt and cytokine expressions in rat retinal hypoperfusion. Neurosci Lett 523(2):93-98

Szegeczki V, Bauer B, Jüngling A, Fülöp BD, Vágó J, Perényi H, Tarantini S, Tamás A, Zákány R, Reglődi D, Juhász T (2019) Age-related alterations of articular cartilage in pituitary adenylate cyclase-activating polypeptide (PACAP) gene-deficient mice. Geroscience 41(6):775-793

Toth D, Szabo E, Tamas A, Juhasz T, Horvath G, Fabian E, Opper B, Szabo D, Maugeri G, D'Amico AG, D'Agata V, Vicena V, Reglodi D (2020) Protective effects of PACAP in peripheral organs. Front Endocrinol 11:377

Vaczy A, Reglodi D, Somoskeoy T, Kovacs K, Lokos E, Szabo E et al (2016) The protective role of PAC1-receptor agonist maxadilan in BCCAO-induced retinal degeneration. $\mathbf{J}$ Mol Neurosci 60:186-194

Wang ZY, Alm P, Håkanson R (1995) Distribution and effects of pituitary adenylate cyclase-activating peptide in the rabbit eye. Neuroscience 69(1):297-308

Werling D, Reglodi D, Kiss P, Toth G, Szabadfi K, Tamas A, Biro Z, Atlasz T (2014) Investigation of PACAP fragments and related peptides in chronic retinal hypoperfusion. J Ophthalmol 2014:563812

Werling D, Banks WA, Salameh TS, Kvarik T, Kovacs LA, Vaczy A et al (2017) Passage through the ocular barriers and beneficial effects in retinal ischemia of topical application of PACAP1-38 in rodents. Int J Mol Sci 18:E675

Ye D, Shi Y, Xu Y, Huang J (2019) PACAP attenuates optic nerve crush-induced retinal ganglion cell apoptosis via activation of the CREB-Bcl-2 pathway. J Mol Neurosci 16:019-01309

Zhang X, Wang N, Barile GR, Bao S, Gillies M (2013) Diabetic retinopathy: neuron protection as a therapeutic target. Int J Biochem Cell Biol 45:1525-1529

Ziello JE, Jovin IS, Huang Y (2007) Hypoxia-inducible factor (HIF)-1 regulatory pathway and its potential for therapeutic intervention in malignancy and ischemia. Yale J Biol Med 80:51-60

Publisher's note Springer Nature remains neutral with regard to jurisdictional claims in published maps and institutional affiliations. 